\title{
Insulin Injection Technique in China Compared with the Rest of the World
}

Zhenqiang Song · Xiaohui Guo · Linong Ji · Xiao Huang •

Laurence J. Hirsch · Kenneth W. Strauss (D)

Received: October 7, 2018 / Published online: October 30, 2018

(C) The Author(s) 2018

\section{ABSTRACT}

Introduction: Approximately 9 million people in China use insulin but little is known of their injection techniques (IT). Our aim was to understand IT in China via direct examination and a detailed survey.

Enhanced digital features To view enhanced digital features for this article go to https://doi.org/10.6084/ m9.figshare.7217702.

Z. Song

Collaborative Innovation Center of Tianjin for Medical Epigenetics, Key Laboratory of Hormones and Development (Ministry of Health), Metabolic Diseases Hospital and Tianjin Institute of Endocrinology, Tianjin Medical University, Tianjin, China

X. Guo

Peking University First Hospital, Beijing, China

L. Ji

Department of Endocrinology, People's Hospital of Peking University, Xicheng District, Beijing, China

X. Huang

Tianjin Metabolic Hospital, Metabolic Diseases

Hospital and Tianjin Institute of Endocrinology,

Tianjin Medical University, Tianjin, China

L. J. Hirsch

BD Diabetes Care, Franklin Lakes, NJ, USA

K. W. Strauss $(\bowtie)$

BD Diabetes Care, Erembodegem, Belgium

e-mail: kenneth.strauss@bd.com
Methods: Injection Technique Questionnaire (ITQ) results of 3853 patients from 20 representative centers in China were compared with the Rest of World (ROW).

Results: Insulin pens are used by $92 \%$ of Chinese insulin injectors, with $>3 / 4$ using 4 - or $5-\mathrm{mm}$ pen needles. This is consistent with Chinese BMI values (and thus subcutaneous fat thickness) being lower than in ROW, raising the risk of IM (intramuscular) injections with longer needles. Total daily insulin dose is $\sim 33 \mathrm{IU}$ in China vs. $45 \mathrm{IU}$ elsewhere. Lipohypertrophy (LH) rates are lower than in ROW, but still found in at least $25 \%$ of Chinese patients. Patients apparently do not realize they have LH or are unaware of the hazards of injecting into LH since many of them do so, and those who do use a mean of $11 \mathrm{IU}$ more of insulin than nonLH patients. This incremental insulin use possibly costs the Chinese health care service around 2 billion RMB annually. Needle reuse is also frequent in China ( $78 \%$ vs. $48 \%$ ROW), and the high cost of pen needles is the main reason patients cite for reusing $(25 \%$ use a single needle $>10 \times$ ).

Conclusion: This study reveals many areas in which Chinese professionals and patients can optimize injection practices and thereby improve outcomes and reduce costs. The official guidelines of the Chinese Diabetes Society, based on the FITTER recommendations, offer a roadmap for reaching this goal.

Funding: BD Diabetes Care. 
Plain Language Summary: Plain language summary available for this article.

Keywords: Infusions; Injections; Insulin; Lipodystrophy; Lipohypertrophy; Needles; Needlestick; Subcutaneous

\section{PLAIN LANGUAGE SUMMARY}

Little is known about the daily practices of Chinese insulin injectors. We queried 3853 insulin-injecting Chinese patients (both T1DM and T2DM) in this regard. Most patients use insulin pens and short (4- or 5-mm needles). Lipohypertrophy affects a quarter of Chinese injectors, and results in the consumption of $11 \mathrm{IU}$ more insulin/day by those affected. Site rotation and needle reuse (main causes of lipohypertrophy) are sub-optimal in China. The Chinese Diabetes Society has recently released guidelines that address these issues.

\section{INTRODUCTION}

The prevalence of diabetes (DM) in China has been increasing since 1980, especially in the economically developed eastern regions [1]. In a single decade, from 2000 to 2010, the reported prevalence increased from $2.6 \%$ to $9.7 \%$ [2]. Given the ongoing epidemic of obesity, hypertension and elevated triglycerides along with dense urbanization and sedentary lifestyles, the prevalence of DM in China is certainly higher now. The most recent estimate (for 2013, but published in 2017) estimates the prevalence of diagnosed and undiagnosed DM at 10.9\% (95\% CI $10.4-11.5 \%$ ) [3]. With a total Chinese population of approximately 1415 million persons [4], that means there are up to 150 million Chinese living with DM today. This estimate concurs with those published by other international sources $[5,6]$.

It is however considerably harder to find reliable estimates for the number of Chinese patients with DM who use insulin. Even more obscure are the types of devices used to deliver insulin, the sites Chinese patients use for injection, their methods or techniques of injection, the nature and prevalence of injecting complications and the means of disposing of used devices in China.

Notwithstanding, a series of important studies has been published recently on Chinese populations who inject insulin. Wang [7] studied the actual metrics of skin and subcutaneous (SC) thickness in 508 adult Chinese patients with DM and showed that their risk for intramuscular (IM) injections was higher than that of western patients because of thinner fat layers. The authors recommended mitigating this risk by use of the shortest pen needles $(4 \mathrm{~mm}$ in length). Jiajia, in a survey from 2010 [8, 10], showed that two-thirds of Chinese insulin-injecting type $2 \mathrm{DM}$ patients (T2DM) were using $5-\mathrm{mm}$ needles, $19 \%$ used $8-\mathrm{mm}$, and $5 \%$ used 6-mm needles. Since then, the Chinese Diabetes Society has strongly recommended the use of short (4- or 5-mm) needles for all Chinese patients who inject insulin [9]. In a study of 401 Chinese adults injecting insulin, Ji [10] showed that lipohypertrophy (LH) was present in more than half $(53.1 \%)$ and was associated with poorer glucose control, despite the fact that these patients were using nearly $1 / 3$ more insulin than patients without LH. One of the aims of our study was to confirm the prevalence of LH and associated insulin usage. The Chinese Diabetes Society has also recommended that patients properly rotate their injection sites and refrain from reusing needles, since incorrect site rotation and frequent needle reuse are known risk factors associated with LH prevalence [9]. However, until our study, the adherence to these recommendations was unknown. Our aim was to understand the injection technique of Chinese patients via direct examination and a detailed questionnaire survey.

In this article we present the results of the Insulin Injection Technique Questionnaire (ITQ) study for China. This survey, performed from 2014 to 2015, involved 3853 insulin-injecting Chinese patients [both type 1 DM (T1DM) and T2DM] and queried all aspects of the insulin injection experience, from choice of device and needle length to the disposal of the used sharps after injection. The Chinese data have already been included within the worldwide results involving 13,289 patients from 42 
countries $[11,12]$, but in the present article we provide vital additional details directly comparing Chinese IT practices vs. those in the Rest of World (ROW, i.e., excluding China).

\section{METHODS}

The ITQ study methodology, including statistical methods, has been described in two previous publications $[11,13]$. These articles describe the type of question asked, validation process, basis for pooling data and selection of sites and patients. We used similar methods in China, and the inclusion criteria (insulin injection for at least 6 months) were the same. The various language versions of the questionnaire (nurse and patient forms) can be found at http://www. fitter4diabetes.com. The technique for $\mathrm{LH}$ detection was similar to that described by Gentile [14]. A total of 3853 Chinese patients participated in the ITQ study, 29\% of the worldwide total. Of these, 3354 patients received a slightly shorter questionnaire (with identical questions to the full questionnaire on all issues involving insulin technique but without those related to ketoacidosis and hospitalizations) and 499 filled out the complete questionnaire. The Chinese results were analyzed with and without the additional 3354 persons. The results of all key parameters were statistically similar between the two groups; hence, we have pooled the two data sets of Chinese patients.

The ITQ was conducted according the principles of the Helsinki Declaration and subsequent amendments. No patient-identifying information was given to the sponsor, and participants were assured their care would not be affected in any way by their choice to participate or not. They were put at no risk by the study and were not remunerated for participation. Therefore, ethics committee (EC) approval was not generally required. It was however obtained whenever requested by local authorities (no EC numbers are provided in China). All 20 participating centers in China (as in ROW) did so voluntarily and without financial incentive. A total of 3853 Chinese participants with DM were included in the ITQ $(\sim 29 \%$ of the total ITQ population). Worldwide as well as China-specific ITQ data are available in an interactive form on Tableau Public Adam Yeung's Profile website [15]. This database contains all the raw ITQ data for both China and ROW (by individual country), and allows the user to select and view results for specific populations, parameters or combinations of parameters.

Not every patient responded to every question in the survey-hence, sample sizes may differ between certain questions or tables. In addition, due to the large Ns, small differences in results for a number of parameters may achieve statistical significance, but have limited clinical implications.

\section{RESULTS}

Table 1 shows the demographic features of our populations. On average, Chinese patients were significantly older than patients from ROW and had a lower mean body mass index (BMI). More Chinese patients had T2DM (94.2\%) than in ROW (64.2\%), and they had used insulin for a significantly shorter time (all differences at $p<0.001)$. Chinese patients had lower HbA1c values $(p=0.020)$ than ROW, but there were no differences in gender $(p=0.095)$ or duration of $\mathrm{DM}(p=0.246)$.

Table 2 gives the therapies and devices used. In China, 92\% of injecting-patients already use insulin pens, $3.4 \%$ still use syringes, $3.0 \%$ use a

Table 1 Demographics of populations studied

\begin{tabular}{lll}
\hline Groups & $\begin{array}{l}\text { China } \\
\boldsymbol{N}=\mathbf{3 8 5 1} \\
\text { Mean }(\mathbf{S D})\end{array}$ & $\begin{array}{l}\text { ROW } \\
\boldsymbol{N}=\mathbf{9 1 9 4} \\
\text { Mean (SD) }\end{array}$ \\
\hline Age (years) & $58.6(13.4)$ & $49.2(19.0)$ \\
BMI & $24.0(3.5)$ & $27.7(6.7)$ \\
Years with DM & $12.9(7.8)$ & $13.2(9.8)$ \\
Years on insulin & $5.9(5.0)$ & $8.9(9.1)$ \\
HbA1c (\%) & $8.32(1.9)$ & $8.46(2.2)$ \\
\% Female & 50.8 & 49.2 \\
\% Type 1 DM & 5.8 & 35.8 \\
\hline
\end{tabular}


Table 2 Therapies and devices used

\begin{tabular}{lll}
\hline Groups & $\begin{array}{l}\text { China } \\
\boldsymbol{N}=\mathbf{3 8 5 2} \\
\text { Mean } \\
(\text { SD })\end{array}$ & $\begin{array}{l}\text { ROW } \\
\boldsymbol{N}=\mathbf{8 8 9 8} \\
\text { Mean } \\
(\text { SD) }\end{array}$ \\
\hline $\begin{array}{l}\text { Regular human insulin } \\
\quad \text { IU/day) }\end{array}$ & $30.6(14.2)$ & $26.9(20.8)$ \\
Fast analog (IU/day) & $26.8(13.4)$ & $32.1(21.9)$ \\
NPH (IU/day) & $21.5(14.4)$ & $31.8(24.5)$ \\
Basal analog (IU/day) & $16.8(7.9)$ & $28.0(19.8)$ \\
Pre-mixes (IU/day) & $33.9(13.7)$ & $44.6(26.6)$ \\
Total daily dose (IU/day) & $32.7(16.1)$ & $49.8(33.1)$ \\
\% Using pens & 92.0 & 82.7 \\
\% Using 4-mm needles & 18.7 & 28.4 \\
\% Using 5-mm needles & 57.7 & 17.6 \\
\% Using 6-mm needles & 11.5 & 20.7 \\
\% Using 8-mm needles & 10.3 & 28.5 \\
\hline
\end{tabular}

combination of pens and syringes, and $0.7 \%$ use pens and pumps. The 5-mm pen needle remains the length of choice for the majority of patients $(57.7 \%)$ compared with only $17.6 \%$ in ROW according to nurse examiners in the ITQ. The 4-mm pen needle, despite only being launched in 2010, is now used by $18.7 \%$ of Chinese injectors $(28.4 \%$ in $\mathrm{ROW})$. The $8-\mathrm{mm}$ needle, considered too long for most Chinese patients [7], is still used by $10.3 \%$ (lower than the $28.5 \%$ in ROW). The Total Daily Dose (TDD) of insulin is significantly lower in China than in ROW ( $33 \mathrm{IU}$ vs. $\sim 50 \mathrm{IU}), p<0.001$.

Table 3 outlines the various injection practices by group. Compared with ROW, the percentage of Chinese patients giving one to two injection times per day ( $75.2 \%$ vs. $40.2 \%)$ was higher, and, correspondingly, the percentage of Chinese giving four or more injections per day ( $16.2 \%$ vs. $46.8 \%$ ) was lower. A higher proportion of Chinese patients reuse needles than in ROW (77.8\% vs. $47.9 \%)$, and among those who reuse, the percent engaged in 'excessive' reuse ( $\geq 5$ times) is also higher $(p<0.001)$. Over $70 \%$ of used needles in China are disposed of directly into the trash including $12.8 \%$ not recapped
Table 3 Injection technique used

\begin{tabular}{|c|c|c|}
\hline Groups & $\begin{array}{l}\text { China } \\
N=3852 \text {, } \\
\%\end{array}$ & $\begin{array}{l}\text { ROW } \\
N=9112, \\
\%\end{array}$ \\
\hline Inject $\geq 4$ times/day & 16.2 & 46.8 \\
\hline Use skin lift ('pinch up’) & 69.6 & 63.1 \\
\hline Reuse needles & 77.8 & 47.9 \\
\hline $\begin{array}{l}\text { Reuse a single needle } \geq 5 \\
\text { times }\end{array}$ & 44.0 & 26.0 \\
\hline $\begin{array}{l}\text { Leave needle under } \\
\text { skin }<10 \mathrm{~s}\end{array}$ & 45.6 & 65.5 \\
\hline Skip injections (any?) & 36.8 & 47.7 \\
\hline Trained by diabetes educators & 59.9 & 45.9 \\
\hline $\begin{array}{l}\text { Injection sites inspected each } \\
\text { visit }\end{array}$ & 24.9 & 30.3 \\
\hline Injection sites never inspected & 51.0 & 32.6 \\
\hline $\begin{array}{l}\text { Received injection training in } \\
\text { last } 6 \text { months }\end{array}$ & 52.2 & 55.6 \\
\hline $\begin{array}{l}\text { Never received injection } \\
\text { training }\end{array}$ & 12.9 & 13.8 \\
\hline $\begin{array}{l}\text { Put used needles into the } \\
\text { trash with the cap on }\end{array}$ & 58.0 & 43.3 \\
\hline $\begin{array}{l}\text { Used needles put into the } \\
\text { trash without recapping }\end{array}$ & 12.8 & 4.4 \\
\hline
\end{tabular}

before disposal (vs. 4.4\% ROW), a significant public health hazard.

In data not shown, we found that $93.4 \%$ of Chinese patients stored insulin in the refrigerator before opening it ( $88.3 \%$ in ROW). However, after opening it there was no significant difference between China and ROW in the storage method $(p=0.546)$, with most patients leaving it at room temperature, as recommended by the manufacturers. Of those who stored opened insulin in the fridge, $67.7 \%$ of Chinese patients warmed insulin up to room temperature before injecting, while in ROW the rate was $55.6 \% \quad(p<0.001)$. Fewer Chinese patients reported skipping injections $(36.8 \%)$ than in ROW (47.9\%). Even when Chinese 
patients did skip injections, they did so significantly less often than in ROW $(p<0.001)$.

Nearly $60 \%$ of Chinese patients got their injection training from Diabetes Educators. However, the rate of Health Care Professional (HCP) examination of injection sites was lower in China than ROW. Specifically, the rate of examining sites routinely every visit or even once a year was significantly lower in China than in ROW ( $p<0.001$ for both parameters). Over half of Chinese injectors report their sites have never been inspected (vs. nearly one-third of ROW). The percentage of Chinese patients receiving training in injections, in both the short and long term, was lower than in ROW $(p<0.001)$.

Table 4 presents the complications reported by patients or observed by nurses, and Table 5 outlines Site Rotational Methods. LH was found by HCPs at one or more injecting sites in $25.0 \%$

Table 4 Injection complications found or reported

\begin{tabular}{|c|c|c|}
\hline Groups & $\begin{array}{l}\text { China } \\
N=3727, \\
\%\end{array}$ & $\begin{array}{l}\text { ROW } \\
N=8437 \\
\quad \%\end{array}$ \\
\hline $\begin{array}{l}\text { Lipohypertrophy (LH) found } \\
\text { by nurse at one or more } \\
\text { sites }\end{array}$ & 25.0 & 43.7 \\
\hline Abdominal LH seen by nurse & 16.3 & 17.0 \\
\hline Abdominal LH felt by nurse & 23.2 & 20.6 \\
\hline Thigh LH seen by nurse & 5.4 & 9.9 \\
\hline Thigh LH felt by nurse & 6.7 & 11.3 \\
\hline Buttock LH seen by nurse & 1.1 & 2.2 \\
\hline Buttock LH felt by nurse & 2.2 & 2.8 \\
\hline Arm LH seen by nurse & 3.8 & 11.6 \\
\hline Arm LH felt by nurse & 5.9 & 13.9 \\
\hline $\begin{array}{l}\text { Always inject into } \mathrm{LH}, \\
\text { reported by patient }\end{array}$ & 5.8 & 16.6 \\
\hline $\begin{array}{l}\text { Injections hurt, reported by } \\
\text { patient }\end{array}$ & 68.3 & 54.2 \\
\hline $\begin{array}{l}\text { Injections hurt always or } \\
\text { often (several times/week), } \\
\text { reported by patient }\end{array}$ & 4.0 & 23.6 \\
\hline
\end{tabular}

Table 5 Site rotation method

\begin{tabular}{|c|c|c|}
\hline Groups & $\begin{array}{l}\text { China } \\
N=3852 \\
\quad \%\end{array}$ & $\begin{array}{l}\text { ROW } \\
N=9112, \\
\quad \%\end{array}$ \\
\hline $\begin{array}{l}\text { Patient claims to rotate } \\
\text { injection sites }\end{array}$ & 92.0 & 83.2 \\
\hline $\begin{array}{l}\text { HCW believes patient rotates } \\
\text { sites correctly }\end{array}$ & 77.3 & 70.0 \\
\hline $\begin{array}{l}\text { Patient responses about } \\
\text { specific method used }{ }^{\mathrm{b}}\end{array}$ & & \\
\hline $\begin{array}{l}\text { I move back and forth from } \\
\text { right side of my body to left }\end{array}$ & 56.2 & 43.8 \\
\hline $\begin{array}{l}\text { I move from one injection site } \\
\text { to another }\end{array}$ & 20.7 & 34.3 \\
\hline $\begin{array}{l}\text { I inject about a finger's } \\
\text { breadth }(1 \mathrm{~cm}) \text { from } \\
\text { where I previously } \\
\text { injected }\end{array}$ & 15.7 & 30.5 \\
\hline $\begin{array}{l}\text { My injections describe a } \\
\text { circle around my injection } \\
\text { sites }\end{array}$ & 6.4 & 14.7 \\
\hline $\begin{array}{l}\text { My injections describe } \\
\text { lines across my injection } \\
\text { sites }\end{array}$ & 1.0 & 7.2 \\
\hline
\end{tabular}

of Chinese patients compared with $43.7 \%$ in ROW $(p<0.001)$. Rates did not differ at abdominal and buttock sites, but Chinese values for LH in the thigh and arm were significantly lower than in ROW $(p=0.025$ and $p<0.001$, respectively). More than $68 \%$ of Chinese patients indicated pain at any time with their injections, but only $4 \%$ said their injection hurt always or often (defined as several times per week). Corresponding rates for ROW were $54.2 \%$ and $23.6 \%$, respectively $(p<0.001)$. Only about 1 in 20 Chinese patients report always injecting into $\mathrm{LH}$, while in ROW the ratio is 1 in $7(p<0.001)$. 
Table 6 Glycemic profile

\begin{tabular}{|c|c|c|}
\hline Groups & $\begin{array}{l}\text { China } \\
N=499, \\
\%\end{array}$ & $\begin{array}{l}\text { ROW } \\
N=9098, \\
\%\end{array}$ \\
\hline DKA in last 6 months & 16.2 & 17.5 \\
\hline $\begin{array}{l}\text { Frequent symptomatic } \\
\text { hypoglycemia }^{\text {a }}\end{array}$ & 49.0 & 57.5 \\
\hline $\begin{array}{l}\text { Frequent unexpected } \\
\text { hypoglycemia }\end{array}$ & 11.2 & 19.6 \\
\hline $\begin{array}{l}\text { Hospitalized for hypoglycemia } \\
\text { in last } 6 \text { months }\end{array}$ & 6.4 & 8.4 \\
\hline Frequent hyperglycemia $^{c}$ & 58.1 & 46.0 \\
\hline Glucose variability $^{\mathrm{d}}$ & 33.2 & 35.1 \\
\hline
\end{tabular}

a 'Frequent symptomatic hypoglycemia' is defined as the occurrence of $\geq 1$ symptom of low sugar (e.g., palpitations, tiredness, sweating, strong hunger, dizziness, tremor) and a confirmed blood glucose meter reading $\leq 60 \mathrm{mg} / \mathrm{dl}$ $(3.3 \mathrm{mM} / \mathrm{l})$ occurring $\geq 1$ times weekly

b 'Frequent unexpected hypoglycemia' is defined as hypoglycemia occurring $\geq 1$ times weekly in the absence of a definable precipitating event such as a change in medication, diet or activity

c 'Frequent hyperglycemia' is defined as blood glucose values $>250 \mathrm{mg} / \mathrm{dl}[13.9 \mathrm{mM} / \mathrm{l}]$ occurring $\geq 11$ times weekly

d 'Glycemic variability' is the presence of blood glucose oscillations from $<60 \mathrm{mg} / \mathrm{dl}(3.3 \mathrm{mM} / \mathrm{l})$ to $>250 \mathrm{mg} / \mathrm{dl}$ $(13.9 \mathrm{mM} / \mathrm{l})$ at least three times a week in an unpredictable and unexplained fashion and evidence of such a pattern for at least the previous 6 months. It should be noted that these glucose values were obtained by episodic BGM and not by CGM technology

Table 6 gives the resultant glucose findings, including reported rates of DKA, hyper-and hypoglycemia and glucose variability (Of note, Table 6 does not include those patients who filled out the shortened questionnaire). About one-sixth of patients (China and ROW) reported an episode of DKA in the past 6 months. The percentages of frequent symptomatic hypoglycemia within the last 6 months in China and ROW were $49.0 \%$ and $57.5 \%$, respectively $(p<0.001)$. Furthermore, the rate of severe hypoglycemia requiring assistance (data not shown) and that of frequent unexpected
Table 7 Participating centers

\begin{tabular}{|c|c|c|}
\hline Region & City & Hospital name \\
\hline \multirow[t]{3}{*}{ North } & Beijing & $\begin{array}{l}\text { Peking University No. 3rd } \\
\text { Hospital } \\
\text { Peking University First Hospital } \\
\text { Beijing Haidian Hospital }\end{array}$ \\
\hline & Tianjin & $\begin{array}{l}\text { Tianjin People's Hospital } \\
\text { Tianjin Yellow River Hospital }\end{array}$ \\
\hline & Jinan & $\begin{array}{l}\text { Shandong Province-owned } \\
\text { Hospital } \\
\text { Second Hospital of Shandong } \\
\text { University }\end{array}$ \\
\hline \multirow[t]{3}{*}{ East } & Nanjing & $\begin{array}{l}\text { Nanjing First Hospital } \\
\text { Jiangsu Provincial Authority } \\
\text { Hospital }\end{array}$ \\
\hline & Shanghai & $\begin{array}{l}\text { Shanghai Tenth People's Hospita } \\
\text { Zhongshan Hospital Affiliated of } \\
\text { Fudan University } \\
\text { Shanghai Punan Hospital }\end{array}$ \\
\hline & Hangzhou & $\begin{array}{l}\text { Hangzhou Tradition Chinese } \\
\text { Medicine Hospital } \\
\text { Hangzhou Xiaoshan People's } \\
\text { Hospital } \\
\text { Zhejiang Provincial Traditional } \\
\text { Chinese Medicine Hospital }\end{array}$ \\
\hline South & Guangzhou & $\begin{array}{l}\text { First Affiliated Hospital of } \\
\text { Zhongshan University } \\
\text { Third Affiliated Hospital of } \\
\text { Zhongshan University } \\
\text { Guangdong Provincial People's } \\
\text { Hospital }\end{array}$ \\
\hline West & Chengdu & $\begin{array}{l}\text { West China Hospital } \\
\text { Sichuan Provincial People's } \\
\text { Hospital }\end{array}$ \\
\hline
\end{tabular}

hypoglycemia were lower in China as well (both $p<0.001)$. There was no statistically significant difference in the rate of hospitalizations for hypoglycemia. 


\section{DISCUSSION}

The Chinese ITQ study, involving 3853 patients from 20 centers in 8 cities (Table 7), was part of a worldwide survey conducted in 2014-2015 involved 13,289 subjects from 42 countries $[11,12]$. That survey showed that LH was present in nearly $1 / 3$ of insulin injectors worldwide. We consider this an underestimate since most HCPs conducting the ITQ were not trained in LH detection before the study. By step-wise regression analysis, incorrect rotation and years on insulin were the most important factors associated with LH $(p<0.001)$, while needle reuse is significantly but slightly less strongly associated $(p=0.023)$.

There was also a strong association in the worldwide ITQ between the presence of $\mathrm{LH}$ and the TDD of insulin, with over $10 \mathrm{IU}$ more of insulin on average being consumed in those with $\mathrm{LH}(\mathrm{LH}+)$ than those without LH (LH-). All currently used types of insulins are associated with the risk of $\mathrm{LH}$, even newer analogs, as are all lengths of needles. The presence of LH is associated with $0.5 \%$ higher $\mathrm{HbA} 1 \mathrm{c}$ values on average.

Ji et al. recently reported LH prevalence in China of 53.1\% [16]. LH+ patients in that study had higher HbA1c values than their LH- counterparts $[8.2 \%$ vs. $7.7 \%(66$ vs. $61 \mathrm{mmol} / \mathrm{mol})$, respectively]. LH+ patients also consumed $11 \mathrm{IU}(0.13 \mathrm{IU} / \mathrm{kg}$ or $31.7 \%)$ more insulin per day (38 vs. 27 IU). Daily consumption of insulin by $\mathrm{LH}+$ cost RMB 9.5 vs. 6.8 in LH- subjects. $\mathrm{LH}+$ patients also reused needles more often and rotated sites less frequently. The authors conservatively extrapolated their results to the estimated 9 million insulin-injecting patients in China and concluded that LH-related excess insulin costs were approximately 2 billion RMB (290 million USD) annually. Famulla [17] has clearly shown that the increased consumption of insulin by those with LH is due to impaired insulin absorption (and action). Theirs was the only reported crossover euglycemic clamp study comparing insulin pharmacokinetics (PK) and pharmacodynamics (PD) when injected into areas of LH vs. normal tissue.

To prevent (or cure) LH, patients must carefully rotate their injection sites, a change that often requires that patients expand the zones into which they inject [18-21]. The vast majority of Chinese patients (92.0\%) in the ITQ claim to rotate their injection sites (the best defense against LH), and even Chinese HCPs report most (77.3\%) patients correctly rotate, i.e., leaving a space at least $1 \mathrm{~cm}$ between new injections and any old ones. However, when the rotation method was specifically queried it became clear that most Chinese patients use an inadequate rotational method (Table 5, italic options). Trends are similar in ROW, but even fewer Chinese use an adequate method (Table 5, bold options) than in ROW ( $p<0.001)$.

Hence, it is clear that more effort must go into teaching Chinese patients what correct rotation is and how to perform it. When injecting over wider areas, however, HCPs may introduce an additional risk, that of giving injections IM. IM injections change variably (i.e., accelerate) the PK of insulin, especially if the muscle is actively working [22]. To reduce the risk of IM injections, but still provide for wider injection zones, it is imperative that patients use the shortest needles possible. In addition, when a patient changes from injecting into areas of $\mathrm{LH}$ to sites without $\mathrm{LH}$, it is advisable to simultaneously reduce the dose of insulin by $10-20 \%$ and to then titrate based on BGM [12, 23] to minimize the risk of hypoglycemia.

Our data show that most Chinese patients already use the 5-mm needle and that use of the $4-\mathrm{mm}$ needle is growing. The $4-\mathrm{mm}$ pen needle was introduced in 2010. The impetus for this 'shift to short' was the publication of a series of studies in persons with diabetes, which defined the mean skin thickness as $2.0-2.5 \mathrm{~mm}[24,25]$. One of these studies came from China [26]. It agreed with other studies done in India [27], the Philippines [28], Korea [29], the USA [24], South Africa [30] and Italy [31], all showing essentially similar results but in different patient and ethnic populations.

The span of SC fat is the critical factor informing both the optimal needle length and the preferred technique for injection (e.g., angling the needle or lifting a skin fold). This distance also determines the risk of IM injections $[32,31]$. The higher the BMI, the thicker 
is the SC $[24,32]$. Chinese patients in our study had significantly lower BMI than those in ROW (Table 1). Wang [7] has published the dimensions of SC thickness in 508 adult Chinese patients with DM. It is clear that the risk for IM injections is considerable in Chinese patients, significantly higher than in western patients with much higher BMI values.

Although fewer patients in China still use the $8-\mathrm{mm}$ needle than in ROW $(10.3 \%$ vs. $28.5 \%$ ), its use is still worrisome, given the lower BMI in China (Table 2). There seems to be a downward trend in the use of this needle, and Chinese HCPs should encourage this. Studies in various countries comparing many needles have clearly shown that the needle length has no effect on glucose control, including in overweight and obese patients [33-42]. Therefore, Chinese HCPs should not hesitate to move their patients from the $8-\mathrm{mm}$ needle to shorter lengths. If the 4-mm length is not available, 5-mm pen needles can be used with a lifted skin fold for additional safety, especially in slim Chinese patients or those injecting into the thigh. Injecting the $6-\mathrm{mm}$ needles at a $45^{\circ}$ angle converts the injection depth to approximately $4 \mathrm{~mm}$, another option whenever 4 -mm needles are not available.

Chinese patients have a notably high needle reuse rate-nearly $78 \%$ of patients (Table 3 ). Reusing needles is a common practice also in ROW-slightly under one-half. Patients often cite convenience and cost concerns as the reasons. We found the latter to be the main factor in China, related to inconsistent reimbursement policies for pen needles across cities and provinces. Quite a few studies have now shown an association of needle reuse with LH $[16,43-47]$, especially when the reuse is excessive ( $\geq 5$ times/needle) [46] as it is in China (44\%). In the China LH study by Ji et al. [11], median reuse frequency was 13 uses/single needle in LH+ vs. 7.5 in LH- patients. Injection pain, which was present in a majority of Chinese patients (Table 4), can also be associated with needle reuse [48]. Of note, only $4 \%$ of Chinese ITQ respondents indicated pain with each injection or several times per week-indicating that today's pens with shorter and narrower diameters are acceptable to the patients using them in terms of injection comfort.

A subset of Chinese respondents to the ITQ reported an episode of DKA in the last 6 months in $16.2 \%$ compared with $17.5 \%$ in ROW (Table 6). This frequency appears somewhat high, given that $<6 \%$ of respondents in China had type 1 diabetes. However, the reported rate was similar in ROW patients, $\sim 35 \%$ of whom have type 1 diabetes. These findings warrant additional evaluation.

The Chinese Diabetes Society has taken the lead on insulin injection education over the last decade. For a number of parameters in our study, China is ahead of ROW, and this may be a consequence of their efforts. Education in this field appears to work. A UK study [49] showed that education focused on systematic site rotation, use of the 4-mm pen needle and non-reuse of needles led to the disappearance or reduction in size of a significant percentage of LH lesions after only 6 months. Mean patient HbA1c values decreased by over $4 \mathrm{mmol} / \mathrm{l}$ and the prevalence of glucose variability and unexplained hypoglycemia fell as well. Mean TDD values decreased by 5.6 IU. Italian [50], French [51] and Russian [52] studies showed similar results. Currently, there is a randomized controlled interventional study ongoing in Tianjin, China, testing the efficacy of injection training and 4-mm needle use among Chinese injectors with LH. Results should be available soon.

\section{Limitations of the Study}

An important limitation of our data is that the results are based on surveys completed by patients/families and may be subject to recall bias, especially as it is related to recall of injection education that may have occurred months or years earlier and on a physical examination of injection sites at clinical visits. We have tried to mitigate this bias by including a nurse questionnaire that asked many of the same questions and attempted to verify, or not, the patients' answers. 


\section{CONCLUSION}

Our study has shown that insulin pen use is implemented by $>90 \%$ of Chinese insulin injectors with $>3 / 4$ using either the 4 - or $5-\mathrm{mm}$ pen needles. This is appropriate since Chinese BMI values (and thus SC thickness depth) are lower than in ROW, raising the risk of IM injections with longer needles. LH rates are lower than in ROW, but are still found in at least $1 / 4$ of Chinese patients (another study demonstrated $53.1 \%$ prevalence of $\mathrm{LH}$, but in it the HCPs may have been better trained in $\mathrm{LH}$ diagnosis [16]). Patients apparently do not realize they have $\mathrm{LH}$ or are unaware of the hazards of injecting into LH since many of them do so. This practice may be costing the Chinese health care service up to 2 billion RMB (290 million USD) a year because of poor absorption of insulin injected into LH [16]. Over 90\% of Chinese patients claim to rotate their injection sites, but on close questioning their rotation methods are not found to be adequate for preventing $\mathrm{LH}$. Needle reuse is also common in China with a high frequency of single-needle reuse; the out-of-pocket cost of pen needles due to lack of reimbursement is the main reason patients cite for reusing. Consciousness about proper needle disposal appears rather weak among Chinese patients, with millions of used needles being disposed into the public garbage with their tip still exposed, a major hazard for needle-stick injuries. The official guidelines of the Chinese Diabetes Society [9], based on the FITTER recommendations [23] offer a roadmap for improving injection practice in the country.

\section{ACKNOWLEDGEMENTS}

Our sincerest thanks go to the 3853 patient in the 20 participating centers in China along with their doctors, nurses and patients. (See Table 7).

Funding. BD Diabetes Care sponsored this study by reimbursing hospitals for time spent and paying publication costs for this article. No health care professional or patient received payment for participating in the study and no payments were given to any author for publication of this article. All authors had full access to all of the data in this study and take complete responsibility for the integrity of the data and accuracy of the data analysis.

Authorship. All named authors meet the International Committee of Medical Journal Editors (ICMJE) criteria for authorship for this manuscript, take responsibility for the integrity of the work as a whole and have given final approval to the version to be published. All authors had full access to all of the data in this study and take complete responsibility for the integrity of the data and accuracy of the data analysis.

Prior Publications. This article is another in a series of country-specific analyses of the worldwide ITQ survey results. Two previous publications have appeared entitled Indian Injection Technique Study: Population Characteristics and Injection Practice [13] and Indian Injection Technique Study: Injecting Complications, Education, and the Health Care Professional [53]. Two similar articles summarizing the ITQ results in Turkey are under preparation, as is one from Brazil.

Disclosures. Kenneth W. Strauss is an employee of BD. Laurence J. Hirsch is an employee of $\mathrm{BD} . \mathrm{BD}$ is a manufacturer of injecting devices. Zhenqiang Song, Xiaohui Guo, Linong Ji and Xiao Huang have nothing to disclose.

Ethics Guidelines. All procedures performed in studies involving human participants were in accordance with the ethical standards of the institutional and/or national research committee and with the 1964 Helsinki Declaration and its later amendments or comparable ethical standards. Informed consent was obtained from all individual participants included in the study. No participant-identifying information was made available to the sponsor, and participants were informed that their care would not be affected in any way by their participation. They were not put at risk in any way by the study and were not paid to participate. Ethics committee approval was therefore not generally required but was obtained whenever specifically 
requested by a center and/or by local regulations. All 20 participating centers from 8 cities in China (as in the Rest of World [ROW]) did so willingly and without financial incentive.

Data Availability. Worldwide as well as country-specific ITQ survey data (including China) are available at Tableau Public Adam Yeung's Profile website, http://tabsoft.co/ 23V6ofi. This database contains all the raw ITQ data, for both China and ROW (by individual country), and allows the user to select and view results for specific populations, parameters or combinations of parameters. This site allows the generation of all data sets used in the current report.

Open Access. This article is distributed under the terms of the Creative Commons Attribution-NonCommercial 4.0 International License (http://creativecommons.org/licenses/ by-nc/4.0/), which permits any noncommercial use, distribution, and reproduction in any medium, provided you give appropriate credit to the original author(s) and the source, provide a link to the Creative Commons license, and indicate if changes were made.

\section{REFERENCES}

1. Zuo H, Shi Z, Hussain A. Prevalence, trends and risk factors for the diabetes epidemic in China: a systematic review and meta-analysis. Diabetes Res Clin Pract. 2014;104(1):63-72. https://doi.org/10.1016/j. diabres.2014.01.002 (Epub 2014 Jan 8).

2. Li H, Oldenburg B, Chamberlain C, O'Neil A, Xue B, Jolley D, Hall R, Dong Z, Guo Y. Diabetes prevalence and determinants in adults in China mainland from 2000 to 2010: a systematic review. Diabetes Res Clin Pract. 2012;98(2):226-35. https:// doi.org/10.1016/j.diabres.2012.05.010 (Epub 2012 Jun 1).

3. Wang L, Gao P, Zhang M, et al. Prevalence and ethnic pattern of diabetes and prediabetes in China in 2013. JAMA. 2017;317(24):2515-23. https://doi.org/10.1001/jama.2017.7596.

4. http://www.worldometers.info/world-population/ china-population/. Accessed 16 June 2018.
5. International Diabetes Federation. Diabetes Atlas. 7th ed. Brussels, Belgium: International Diabetes Federation; 2015. http://www.diabetesatlas. org/. Accessed 16 May 2018.

6. Guariguata L, Whiting DR, Hambleton I, Beagley J, Linnenkamp U, Shaw JE. Global estimates of diabetes prevalence for 2013 and projections for 2035 . Diabetes Res Clin Pract. 2014;103(2):137-49.

7. Wang W, et al. Skin and subcutaneous tissue thickness at insulin injection sites in Chinese diabetes patients: clinical implications. Diabetes Metab. 2016;42:374-7.

8. Jiajia J, Qingqing L. Insulin pen injection technique survey in patients with type 2 diabetes in mainland China in 2010. CMRO. 2014;30:1087-93.

9. Ji L, Guo X, Huang J, et al. Chinese guideline for diabetic injection technology. Chin J Diabetes Mellitus. 2017;9(2):79-105.

10. Ji L, Sun Z, Li Q, Qin G, Wei Z, Liu J, Chandran AB, Hirsch LJ. Lipohypertrophy in China: prevalence, risk factors, insulin consumption, and clinical impact. Diabetes Technol Ther. 2017;19(1):61-7. https://doi.org/10.1089/dia.2016.0334.

11. Frid $\mathrm{AH}$, et al. Worldwide injection technique questionnaire study: population parameters and injection practices. Mayo Clin Proc. 2018;91(9):1212-1223. Open Access at: http:// www.mayoclinicproceedings.org/article/S00256196(16)30322-6/fulltext. Accessed 12 May 2018.

12. Frid $\mathrm{AH}$, et al. Worldwide injection technique questionnaire study: injecting complications and role of the professional. Mayo Clin Proc. 2018;91(9):1224-1230. Open Access at: http:// www.mayoclinicproceedings.org/article/S00256196(16)30326-3/fulltext. Accessed 12 May 2018.

13. Kalra S, Mithal A, Sahay R, et al. Indian injection technique study: population characteristics and injection practices. Diabetes Ther. 2017;8(3): 637-57. https://doi.org/10.1007/s13300-017-0243x (Epub 2017 Mar 13).

14. Gentile $S$ et al. Springerplus. A suitable palpation technique allows to identify skin lipohypertrophic lesions in insulin-treated people with diabetes. 2016;5:563. https://doi.org/10.1186/s40064-0161978-y (eCollection 2016).

15. ITQ survey data. Tableau Public Adam Young's Profile website: http://tabsoft.co/23V6ofi. Accessed 12 May 2018.

16. Ji L, Sun Z, Li Q, Qin G, Wei Z, Liu J, Chandran AB, Hirsch LJ. Lipohypertrophy in China: prevalence, risk factors, insulin consumption, and clinical 
impact. Diabetes Technol Ther. 2017;19(1):61-7. https://doi.org/10.1089/dia.2016.0334.

17. Famulla S, Hövelmann U, Fische A, et al. Insulin injection into lipohypertrophic tissue: blunted and more variable insulin absorption and action and impaired postprandial glucose control. Diabetes Care. 2016;39:1486-92. https://doi.org/10.2337/ dc16-0610.

18. Gentile S, Strollo F, Della Corte T, Marino G, Guarino G. Insulin related lipodystrophic lesions and hypoglycemia: double standards? Diabetes Metab Syndr. 2018. https://doi.org/10.1016/j. dsx.2018.04.023.

19. Gentile S, Strollo F, Corte TD, Marino G, Guarino G, Italian Study Group on Injection Techniques. Skin complications of insulin injections: A case presentation and a possible explanation of hypoglycaemia. Diabetes Res Clin Pract. 2018;138:284-287. https://doi.org/10.1016/j.diabres.2018.02.005 (Epub 2018 Feb 8).

20. Gentile S, Guarino G, Giancaterini A, Guida P, Strollo F, AMD-OSDI Italian Injection Technique Study Group. A suitable palpation technique allows to identify skin lipohypertrophic lesions in insulintreated people with diabetes. Springerplus. 2016;5:563. https://doi.org/10.1186/s40064-0161978-y (eCollection 2016).

21. Gentile S, Strollo F, Guarino G, Giancaterini A, Ames PRJ, Speese K, Guida P, Strauss K, on behalf of the AMDOSDI Italian Injection Technique Study Group. Factors hindering correct identification of unapparent lipohypertrophy. J Diab Metab Dis Contr. 2016;3:00065. https://doi.org/10.15406/ jdmdc.2016.03.00065.

22. Vaag A, et al. Variation in absorption of $\mathrm{NPH}$ insulin due to Intramuscular injection. Diabetes Care. 1990;13(1):74-6.

23. Frid $\mathrm{AH}$, et al. New insulin delivery recommendations. Mayo Clin Proc. 2018;91(9):1231-1255. Open Access at: http://www.mayoclinic proceedings.org/article/S0025-6196(16)30321-4/ fulltext. Accessed 12 May 2018.

24. Gibney MA, Arce CH, Byron KJ, Hirsch LJ. Skin and subcutaneous adipose layer thickness in adults with diabetes at sites used for insulin injections: implications for needle length recommendations. Curr Med Res Opin. 2010;26(6):1519-30.

25. Hirsch L, Klaff L, Bailey T, Gibney M, Albanese J, Qu S, Kassler-Taub K. Comparative glycemic control, safety and patient ratings for a new $4 \mathrm{~mm} \backslash 32 \mathrm{G}$ insulin pen needle in adults with diabetes. Curr Med Res Opin. 2010;26:1531-41.
26. Wang W, Guo X, Shen G, et al. Skin and subcutaneous tissue thickness at insulin injection sites in Chinese diabetes patients: clinical implications. Diabetes Metab. 2016;42(5):374-7.

27. Jain SM, Pandey K, Lahoti A, Rao PK. Evaluation of skin and subcutaneous tissue thickness at insulin injection sites in Indian, insulin naïve, type- 2 diabetic adult population. Indian J Endocrinol Metab. 2013;17(5):864-70.

28. Catambing I, Villa M. Ultrasonographic measurement of skin and subcutaneous thickness at insulin injection sites among adult filipinos with diabetes. J ASEAN Feder Endocr Soc. 2014;29(1):24-32.

29. Sim KH, Hwang MS, Kim SY, Lee HM, Chang JY, Lee MK. The appropriateness of the length of insulin needles based on determination of skin and subcutaneous fat thickness in the abdomen and upper arm in patients with type 2 diabetes. Diabetes Metab J. 2014;38(2):120-33.

30. Marran K, Segal D. SKINNY-skin thickness and needles in the young. S Afr J CH. 2014;8(3):92-5. https://doi.org/10.7196/SAJCH.687.

31. Lo Presti D, Ingegnosi C, Strauss K. Skin and subcutaneous thickness at injecting sites in children with diabetes: ultrasound findings and recommendations for giving injection. Pediatr Diabetes. 2012;13(7):525-33.

32. Hirsch L, Byron K, Gibney M. Intramuscular risk at insulin injection sites-measurement of the distance from skin to muscle and rationale for shorter-length needles for subcutaneous insulin therapy. Diabetes Technol Ther. 2014;16(12):867-73.

33. Kreugel G, Keers JC, Jongbloed A, Verweij-Gjaltema $\mathrm{AH}$, Wolffenbuttel BHR. The influence of needle length on glycemic control and patient preference in obese diabetic patients. Diabetes. 2009;58:A117.

34. Hirsch L, Klaff L, Bailey T, et al. Comparative glycemic control, safety and patient ratings for a new $4 \mathrm{~mm} \times 32 \mathrm{G}$ insulin pen needle in adults with diabetes. Curr Med Res Opin. 2010;26(6):1531-41.

35. Schwartz S, Hassman D, Shelmet J, et al. A multicenter, open-label, randomized, two-period crossover trial comparing glycemic control, satisfaction, and preference achieved with a 31 gauge $\times 6 \mathrm{~mm}$ needle versus a 29 gauge $\times 12.7 \mathrm{~mm}$ needle in obese patients with diabetes mellitus. Clin Ther. 2004;26(10):1663-78.

36. Ross SA, Jamal R, Leiter LA, et al. Evaluation of $8 \mathrm{~mm}$ insulin pen needles in people with type 1 and type 2 diabetes. Pract Diabetes Int. 1999;16(5):145-8. 
37. Strauss K, Hannet I, McGonigle J, et al. Ultra-short $(5 \mathrm{~mm})$ insulin needles: trial results and clinical recommendations. Pract Diabetes Int. 1999;16(7): 218-21.

38. Kreugel G, Keers JC, Kerstens MN, Wolffenbuttel $\mathrm{BH}$. Randomized trial on the influence of the length of two insulin pen needles on glycemic control and patient preference in obese patients with diabetes. Diabetes Technol Ther. 2011;13(7):737-41.

39. Iwanaga M, Kamoi K. Patient perceptions of injection pain and anxiety: a comparison of NovoFine 32-gauge tip $6 \mathrm{~mm}$ and Micro Fine Plus 31-gauge $5 \mathrm{~mm}$ needles. Diabetes Technol Ther. 2009;11(2):81-6.

40. McKay M, Compion G, Lytzen L. A comparison of insulin injection needles on patients' perceptions of pain, handling, and acceptability: a randomized, open-label, crossover study in subjects with diabetes. Diabetes Technol Ther. 2009;11(3):195-201.

41. Nagai Y, Ohshige T, Arai K, Kobayashi H, Sada Y, Ohmori S. Comparison between shorter straight and thinner microtapered insulin injection needles. Diabetes Technol Ther. 2013;15(7):550-5.

42. Hirose T, Ogihara T, Tozaka S, Kanderian S, Watada H. Identification and comparison of insulin pharmacokinetics injected with a new 4-mm needle vs 6- and 8-mm needles accounting for endogenous insulin and C-peptide secretion kinetics in non-diabetic adult males. J Diabetes Investig. 2013;4(3): 287-96.

43. De Coninck C, Frid A, Gaspar R, et al. Results and analysis of the 2008-2009 insulin injection technique questionnaire survey. J Diabetes. 2010;2(3):168-79.

44. Vardar B, Kizilci S. Incidence of lipohypertrophy in diabetic patients and a study of influencing factors. Diabetes Res Clin Pract. 2007;77:231-6.

45. Saez-de Ibarra L, Gallego F. Factors related to lipohypertrophy in insulin-treated diabetic patients; role of educational intervention. Pract Diab Int. 1998;15:9-11.

46. Blanco M, Hernández MT, Strauss KW, Amaya M. Prevalence and risk factors of lipohypertrophy in insulin-injecting patients with diabetes. Diabetes Metab. 2013;39(5):445-53.

47. Hirsch L, Ji L, Sun Z, Li Q, et al. Lipohypertrophyprevalence, risk factors and clinical characteristics of insulin-requiring patients in China. DTT. 2015;17(Suppl 1):A57-8.

48. Misnikova I, Dreval A, Gubkina V, Rusanova E. The risk of repeated use of insulin pen needles in patients with diabetes mellitus. J Diabetol. 2011;1:1-5.

49. Smith M, Clapham L, Strauss K. UK lipohypertrophy intervention study. Diabetes Res Clin Pract. 2017;126:248-53.

50. Grassi G, Scuntero P, Trepiccioni R, et al. Optimizing insulin injection technique and its effect on blood glucose control. J Clin Transl Endocrinol. 2014;1:145-150. This is an open access article under the CC BY-NC-ND license (http://creativecommons. org/licenses/by-nc-nd/3.0/). Accessed 12 May 2018.

51. Campinos $\mathrm{C}$, et al. An effective intervention for diabetic lipohypertrophy: results of a randomised, controlled, prospective, multicentre study in France. Diabetes Technol Ther. 2017;19:623-32. https://doi.org/10.1089/dia.2017.0165 (Epub 2017 Oct 23).

52. Misnikova I, Gubkina V, Lakeeva T, Dreval A. A randomized controlled trial to assess the impact of proper insulin injection technique training on glycemic control. Diabetes Ther. 2017;8(6):1309-18. https://doi.org/10.1007/s13300-017-0315-y (Epub 2017 Oct 13).

53. Kalra S, Mithal A, Sahay R, et al. Indian injection technique study: injecting complications, education, and the health care professional. Diabetes Ther. 2017;8(3):659-72. https://doi.org/10.1007/ s13300-017-0244-9 (Epub 2017 Mar 13). 